\title{
Communication
}

\author{
[Comunicação]
}

\section{Neospora caninum antibodies and risk factors in dogs from Lages and Balneário Camboriú, SC}

[Anticorpos contra Neospora caninum e fatores de risco em cães de Lages e Balneário Camboriú, SC]

\author{
A.B. Moura $^{1}$, A.P. Souza ${ }^{1}$, A.A. Sartor ${ }^{1}$, V. Bellato ${ }^{1}$, G.M. Pisetta ${ }^{2}$, \\ E.B. Teixeira ${ }^{2}$, A. Heusser Junior ${ }^{2}$ \\ ${ }^{1}$ Centro de Ciências Agroveterinárias - UDESC \\ Av. Luís de Camões, 2090 \\ 88520-000 - Lages, SC \\ ${ }^{2}$ Médico veterinário
}

Neosporosis was firstly described in dogs with nervous system alterations in Norway and McAllister et al. (1998) confirmed the dog as a definitive host. Canine neosporosis is a disease that can cause severe clinical manifestations, mainly of neuromuscular origin. Despite this, there is a concern from an epidemiologic perspective that dogs can be definitive hosts.

The most severe signs of neosporosis in dogs occur in congenitally infected puppies, with ascending paralysis of the limbs and rigid hyperextension, which can lead to progressive paralysis and death. Difficulty to swallow, accompanied by paralysis of jaw, muscular stiffness, and atrophy and cardiac failure can also be observed. Moreover, the disease can be shown in the generalized form. Severe dermatitis and peritonitis caused by $N$. caninum were already reported as well.

Despite puppies being more commonly affected, adult and/or old dogs can also present severe neosporosis, including deaths. Reproductive disorders, like abortion and stillborn, also occur in bitches with neosporosis. Infected females with subclinical disease can transmit $N$. caninum to their litters, and this can happen successively, during several gestations.

There are worldwide studies regarding canine neosporosis. In Brazil, the incidence of antibodies against $N$. caninum varies from $4.3 \%$ to $58.9 \%$ in dogs from different regions of the Country (Gennari, 2004). The number of domiciled dogs has significantly increased in the last years, making necessary further investigations on several diseases,

Recebido em 20 de novembro de 2010

Aceito em 25 de fevereiro de 2011

E-mail:a2abm@cav.udesc.br among which neosporosis presents a highlighting importance. The non-existence of data about canine neosporosis in Santa Catarina State motivated the present study. So, the aim of this study was to identify risk factors and the occurrence of anti- $N$. caninum antibodies of dogs from the municipalities of Lages and Balneário Camboriú, Santa Catarina State.

Blood samples of 400 domiciled dogs (200 from each municipality) were collected and sent to a Laboratory of Parasitology and Parasitic Diseases for obtention of sera. Samples were stocked at $20^{\circ} \mathrm{C}$ until the processing for the detection of antibodies against $N$. caninum by indirect fluorescence antibody test (IFAT) using tachyzoites of the NC1 strain of $N$. caninum as antigen. Animals that presented titers $\ 50$ were considered positive. Canine positive and negative sera were used as control. Positive sera were diluted in PBS and successively re-diluted two-fold until the end point (from 1:50 to 1:800). Breed, age, gender, type of diet, environment, contact with other animals, and access to street information were obtained by a questionnaire answered by the owners. These data were then tabulated and statistically analyzed by the Fisher's exact and $\chi^{2}$ tests $(\mathrm{P} \leq 0.05)$.

Forty-nine (12.3\%) dogs presented anti- $N$. caninum antibodies. Among the dogs from Lages, 26 (13\%) were positive for $N$. caninum, whereas 23 (11.5\%) from Balneário Camboriú were seropositive. The antibody titers and number of positive animals, respectively, were 1:50 (20), 1:100 (13), 1:200 (10), 1:400 (4), and 1:800 (2). No statistical differences were observed between the occurrence of anti- $N$. caninum antibodies $(\mathrm{P}=0.647)$ in dogs from the two 
studied areas. This is the first report regarding the occurrence and risk factors for the canine neosporosis in Santa Catarina State.

Serological surveillances on canine neosporosis have been conducted in several countries presenting a wide variation in prevalence. In Brazil, Gennari et al. (2002), in São Paulo, found a $10 \%$ N. caninum seropositivity in domiciled and $25 \%$ for stray dogs. Cañón-Franco et al. (2003), studying urban dogs from Monte Negro, RO, observed $8.3 \%$ of positivity; while Oliveira et al. (2004), in Campo Grande, MS, observed a seroprevalence of $26.5 \%$. Jesus et al. (2006), in the cities of Salvador and Lauro de Freitas, BA, found frequencies of 13.3\% and $11.2 \%$ in domiciled and stray dogs, respectively. Teixeira et al. (2006), in São Luís, MA, reported a frequency of $45 \%$ in dogs captured by the Centre for Control of Zoonoses. This demonstrates that also in Brazil the prevalence present a wide range of variation. The disagreement among results from the studies forecited can be attributed to the different techniques and/or cut off applied. Also, the origin of the evaluated populations is an important factor which influences the prevalence of anti- $N$. caninum antibodies, once stray animals and those from rural areas tend to present higher rates of seropositivity because they might be more exposed to sources of infection.

The results of the Fisher's exact and $\chi^{2}$ tests, applied in order to verify the influence of the analyzed variables on the occurrence of antibodies against $N$. caninum, are shown in Table 1 . An association between age and anti- $N$. caninum antibodies was observed $(\mathrm{P}=0.020$, odds ratio $(\mathrm{OR})=2.557$, confidence interval $(\mathrm{CI})$ 95\% 1.165.64) in the present work, with dogs of 13 -monthold or older representing $83.7 \%$ of the positive animals. This fact indicates that the age may correlate with the increase on the possibilities of contact with sources of infection for neosporosis, suggesting a postnatal exposure to the agent. Surveys carried out by and Cañón-Franco et al. (2003), in dogs from urban areas, found a higher occurrence of antibodies for $N$. caninum according different age groups. The same was observed by Oliveira et al. (2004), in Brazil, and by Haddadzadeh et al. (2007) and Collantes-Fernandez et al. (2008) in other countries. On the other hand, Coskun et al. (2000) and Romanelli et al. (2007) did not observed any correlation between age and seroprevalence for canine neosporosis.

Table 1. Frequency of positive dogs (IFAT, $\geq 1: 50$ ) for Neospora caninum from the municipalities of Lages and Balneário Camboriú, Santa Catarina State, in 2007

\begin{tabular}{|c|c|c|c|c|c|c|c|}
\hline \multirow{2}{*}{ Variable } & \multirow{2}{*}{ Category } & \multicolumn{2}{|c|}{ Animals } & \multicolumn{2}{|c|}{ Positive $^{1}$} & \multirow{2}{*}{$\begin{array}{c}\text { Positive }^{2} \\
\%\end{array}$} & \multirow[t]{2}{*}{$\mathrm{P}$} \\
\hline & & $\mathrm{n}$ & $\%$ & $\mathrm{n}$ & $\%$ & & \\
\hline \multirow{2}{*}{ Breed } & Mixed & 250 & 62.5 & 31 & 12.4 & 63.3 & \multirow{2}{*}{0.906} \\
\hline & Pure & 150 & 37.5 & 18 & 12 & 36.7 & \\
\hline \multirow{2}{*}{ Gender } & Male & 223 & 55.8 & 27 & 12.1 & 55.1 & \multirow{2}{*}{0.922} \\
\hline & Female & 177 & 44.2 & 22 & 12.4 & 44.9 & \\
\hline \multirow{2}{*}{ Age } & $<12$ month-old & 125 & 31.2 & 8 & 6.4 & 16.3 & \multirow{2}{*}{0.020} \\
\hline & $>12$ month-old & 275 & 68.8 & 41 & 14.1 & 83.7 & \\
\hline \multirow{3}{*}{ Diet } & Commercial food & 131 & 32.8 & 18 & 13.7 & 36.7 & \multirow{3}{*}{0.818} \\
\hline & Home made & 113 & 28.2 & 13 & 11.5 & 26.5 & \\
\hline & Mixed & 156 & 39 & 18 & 11.5 & 36.8 & \\
\hline \multirow{2}{*}{ Environment } & Cemented & 64 & 16 & 12 & 18.8 & 24.5 & \multirow{2}{*}{0.096} \\
\hline & Grass/Land & 336 & 84 & 37 & 11 & 75.5 & \\
\hline \multirow{2}{*}{$\begin{array}{c}\text { Contact with } \\
\text { other animals }\end{array}$} & Yes & 112 & 28 & 11 & 9.8 & 22.5 & \multirow{2}{*}{0.356} \\
\hline & No & 288 & 72 & 38 & 13.2 & 77.5 & \\
\hline \multirow{2}{*}{ Access to street } & Yes & 206 & 51.5 & 30 & 14.6 & 61.2 & \multirow{2}{*}{0.170} \\
\hline & No & 194 & 48.5 & 19 & 9.8 & 38.8 & \\
\hline Total & & 400 & 100 & 49 & - & - & - \\
\hline
\end{tabular}

Positive $^{1}=$ Relation among the positive animals within a category and the total of animals of its category.

Positive $^{2}=$ Relation among the positive animals within a category and the total of positive animals.

$\mathrm{P}=$ descriptive level of the $\chi 2$ test. 
The dogs maintained on grass/land environment presented tendency $(\mathrm{P}=0.096, \mathrm{OR}=0.537, \mathrm{CI}$ $95 \% 0.26-1.10$ ) to a higher seropositivity for neosporosis. However, the high number of animals maintained in such conditions (84\%) and the small number maintained on cemented conditions did not allow a definite conclusion.

The other variables (breed, gender, diet, contact with other animals, and access to street) did not present association with the occurrence of antibodies against $N$. caninum. Coskun et al. (2000), in Turkey; Oliveira et al. (2004), in Campo Grande, Brazil, and Haddadzadeh et al. (2007), in Teheran, Iran, also did not observe association between gender and the prevalence of anti- N. caninum antibodies. Jesus et al. (2006), in Bahia State, Brazil, did not find statistical difference among gender, age, and breed and the frequency of antibodies anti- $N$. caninum. Patitucci et al. (2001), in Chile, observed higher positivity in dogs feed on domestic food. In
Spain, Collantes-Fernandez et al. (2008) observed a moderate prevalence in dogs of game and stray animals, but without statistical differences with domiciled dogs, indicating that the type of diet can influence the anti-N. caninum seroprevalence.

Even though the variable "access to street" did not present significant association $(\mathrm{P}=0.170$, $\mathrm{OR}=1.57$, CI 95\% 0.85-2.89), regarding the occurrence of anti- $N$. caninum antibodies, a moderate incidence was observed in these category. Among the positive dogs, 61.2\% belonged to this category. Gennari et al. (2002) and Teixeira et al. (2006) observed higher occurrence among stray dogs when compared to domiciled dogs. The same was not observed by Jesus et al. (2006).

Keywords: dog, Neospora caninum, risk factors, epidemiology

\section{RESUMO}

Identificaram-se os fatores de risco e a ocorrência de anticorpos contra Neospora caninum em cães das cidades de Lages e Balneário Camboriú, SC. Amostras de soro de 400 cães domiciliados (200 de cada município) foram processadas para a detecção de anticorpos contra $\mathrm{N}$. caninum pela técnica de imunofluorescência indireta. Informações acerca dos fatores de risco foram obtidas por meio de questionário. Dos 400 cães, 49 (12,3\%) apresentaram anticorpos contra N. caninum. Em Lages, 26 (13\%) foram positivos para N. caninume; em Balneário Camboriú, 23 (11,5\%). Não foram observadas diferenças estatísticas entre as ocorrências de anticorpos contra $\mathrm{N}$. caninum $(P=0,647)$ nas duas cidades. Das variáveis analisadas, somente idade apresentou associação $(P=0.020$, odds ratio $=2.557$, IC 95\%, 1.16-5.64) com a freqüência de cães reagentes ao N. caninum. Dentre os animais positivos, 41 (83,7\%) eram adultos, indicando ocorrência de infecção pós-natal do agente.

Palavras-chave: cão, Neospora caninum, fatores de risco, epidemiologia

\section{REFERENCES}

CAÑÓN-FRANCO, W.A.; BERGAMASCHI, D.P.; LABRUNA, M.B. et al. Prevalence of antibodies to Neospora caninum in dogs from Amazon, Brazil. Vet. Parasitol., v.115, p.71-74, 2003.

COLLANTES FERNANDEZ, E.; GOMEZ BAUTISTA, M.; MIRO, G. et al. Seroprevalence and risk factors associated with Neospora caninum infection in different dog populations in Spain. Vet. Parasitol., v.152, p.148-151, 2008.
COSKUN, S.Z.; AYDYN, L.; BAUER, C. Seroprevalence of Neospora caninum infection in domestic dogs in Turkey. Vet. Rec., v.146, p.649, 2000.

GENNARI, S.M. Neospora caninum no Brasil: situação atual da pesquisa. Rev. Bras. Parasitol. Vet., v.13, supl.1, p.23-27, 2004.

GENNARI, S.M.; YAI, L.E.O.; D'AURIA, S.N.R. et al. Occurrence of Neospora caninum antibodies in sera from dogs of the city of São Paulo, Brazil. Vet. Parasitol., v.106, p.177-1792, 2002. 
HADDADZADEH, H.R.; SADREBAZZAZ, A.; MALMASI, A. et al. Seroprevalence of Neospora caninum infection in dogs from rural and urban environments in Tehran, Iran. Parasitol. Res., v.101, p.1563-1565, 2007.

JESUS, E.E.V.; SANTOS, P.O.M.; BARBOSA, M.V.F. et al. Frequência de anticorpos antiNeospora caninum em cães nos municípios de Salvador e Lauro de Freitas, estado da Bahia, Brasil. Braz. J. Vet. Res. Anim. Sci., v.43, p.5-10, 2006.

McALLISTER, M.M.; DUBEY, J.P. LINDSAY, D.S. et al. et al. Dogs are the definitive hosts of Neospora caninum. Int. J. Vet. Parasitol., v.28, p.1473-1478, 1998.

OLIVEIRA, J.M.; MATOS, M.F.C.; OSHIRO, L.M. et al. Prevalence of anti-Neospora caninum antibodies in dogs in the urban area of Campo Grande, MS, Brazil. Rev. Bras. Parasitol. Vet., v.13, p.155-158, 2004.
PATITUCCI, A.N.; PEREZ, M.J.; ROZAS, M.A. et al. Neosporosis canina: presencia de anticuerpos séricos en poblaciones caninas rurales y urbanas de Chile. Arch. Med. Vet., v.33, p.227-232, 2001.

ROMANELLI, P.R.; FREIRE, R.L.; VIDOTTO, O. et al. Prevalence of Neospora caninum and Toxoplasma gondii in sheep and dogs from Guarapuava farms, Paraná State, Brazil. Res. Vet. Sci., v.82, p.202-207, 2007.

TEIXEIRA, W.C.; SILVA, M.I.S.; PEREIRA, J.G. et al. Frequência de cães reagentes para Neospora caninum em São Luís, Maranhão. Arq. Bras. Med. Vet. Zootec., v.58, p.685-687, 2006. 